\title{
Increasing Business Income of Dairy Goat Crossbreed Etawah Farming in Payageli Village Deli Serdang District
}

\author{
Sukma Aditya Sitepu ${ }^{\left.I^{*}\right)}$ and Julia Marisa ${ }^{2}$ \\ ${ }^{1)}$ Department of Animal Husbandry, Faculty of Sains and Technology, Pembangunan Panca Budi \\ University, Sumatera Utara, Indonesia \\ 2) Department of Agroecotechnology, Faculty of Sains and Technology, Pembangunan Panca Budi \\ University, Sumatera Utara, Indonesia
}

\begin{abstract}
The purpose of this community service were to give an introduction to the farmers about income analysis of Etawah Crossbred Goat business and as well as to find out the income derived in Payageli Village Deli Serdang. The implementation of community service was expected to improve the capability and knowledge of the goat milk farmers, to analyze and separate between the acceptance component and cost components in the same maintenance period. The information could then facilitate the farmers on how to calculate the total income in a period of raising the goat, resulting in the improvement of farmers' welfare. The results showed that the farmers have an ability to analysis their business income, so that they learned how to minimized their production cost to increase their income.
\end{abstract}

Keywords: Dairy goat, Etawah crossbred goat, Income analysis, Production

\begin{abstract}
Abstrak. Tujuan dari pengabdian masyarakat ini adalah untuk memberikan pengetahuan kepada para peternak tentang analisis pendapatan usaha peternakan Kambing Peranakan Etawah serta untuk mengetahui penghasilan yang didapat di Desa Payageli Deli Serdang. Implementasi pengabdian kepada masyarakat diharapkan digunakan untuk meningkatkan kemampuan dan pengetahuan para petani susu kambing dalam menganalisis dan memisahkan antara komponen penerimaan dan komponen biaya dalam periode pemeliharaan yang sama. Informasi tersebut dapat memfasilitasi para petani tentang bagaimana menghitung total pendapatan dalam periode pemeliharaan kambing, yang berakibat pada peningkatan kesejahteraan petani. Hasil penelitian menunjukkan bahwa petani telah memiliki kemampuan untuk menganalisis pendapatan bisnis mereka, sehingga mereka belajar bagaimana meminimalkan biaya produksi untuk meningkatkan pendapatan mereka.
\end{abstract}

Kata Kunci: Analisis pendapatan, Kambing perah, Kambing peranakan etawah, Produksi

Received 8 October 2018 | Revised 12 December 2018 | Accepted 12 March 2019

*Corresponding author at: Jl. Gatot Subroto, Pembangunan Panca Budi University, Medan 20122, Sumatera Utara

E-mail address: sukmaaditya@dosen.pancabudi.ac.id 


\section{Introduction}

Payageli Village, Deli Serdang Regency is one of the locations of the people who do goat business. Medan Sunggal Subdistrict has 7 villages, but from 7 villages only Payageli Village has great potential to develop Etawah Crossbred Goatbusiness, besides that there are 15 breeders who own Etawah Crossbred Goatbut only 5 farmers who join the community are named "RUMAH SUSU". This certainly has an impact on the economy of each farmer, and also has a positive impact on consumers who consume goat's milk. Collaboration and perseverance and budgetary costs that are well managed farmers can grow the business and make the main livelihood. But another thing that to be considered is the analysis of the income of the etawa goat milk business [1].

The phenomenon is that the farmers in the Etawah Crossbred Goat business in Payageli Village, Deli Serdang Regency still consider their business as a side business and do not analyze the income of their Etawah Crossbred Goatbusiness [2, 3]. This resulted in them not knowing exactly and in detail how much income they earned from the Etawah Crossbred Goatbusiness so that they did not know the priority of using the cost well to increase the income of farmers.

Sei Mencirim Village, Jati Dusun II Street is a village where the majority of women work as housewives or do not work outside the home. This is a fundamental reason for choosing Sei Mencirim village as a community service location. Due to the low knowledge of housewives about the importance of entrepreneurship. In addition, it was also caused by a lack of interest and willingness from housewives in this village to start a home business. In fact, housewives actually have the potential to build their own businesses at home, which its outcome can be used for themselves, their families, and neighborhood. One alternative business that tends to be easily developed by housewives is a business in food sector since business in this field does not require a lot of time because it can be executed among the housewives' spare time.

\section{Method}

\section{Materials}

The materials used were power point material, paper, book, ballpoint, calculator and laptop.

\section{Methods}

The method of approach offered to resolve farmers' problems is to provide: 
- Lectures and Discussions. Lecture material (training) is given to participants. After the lecture is finished, it is continued with a discussion (question and answer) and practice directly in the field. The lecture material is:

1. Potential of Etawah Crossbred Goatin Indonesia.

2. Business opportunities for Etawah Crossbred Goatin increasing people's income.

3. Calculation of the costs and revenues of Etawah Crossbred Goatbusiness.

4. Bookkeeping business of Etawah Crossbred Goat.

- $\quad$ Direct practice.

Calculating the costs and revenues as well as make business bookkeeping Etawah Crossbred Goat.

\section{Procedure}

The work procedure before giving the realization of the solution offered is to first make an initial observation, approach through interviews and find the phenomenon of the problem. After observation and then do the assessment socialization problems and find solutions that are going to offer, set priorities for the stages of implementation and further to provide education and practice. At the end of the activity an evaluation of sustainability and results was carried out by observing the bookkeeping of the Etawa breed goat milk business [4].

\section{Result and Discussion}

The community service program was conducted in Payageli Village, Deli Serdang Regency with the theme: " Increasing Business Income Of Dairy Goat Crossbreed Etawah Farming In Payageli Village Deli Serdang District". after that a re-observation is carried out and it is known that there have been several effects of changes in a better direction in accordance with the explanation of the results.

1. Analysis of changes in how to calculate the income of the Etawah Crossbred Goatmilk business. At first the Etawah Crossbred GoatBreeders business breeders did not calculate the costs and income of the Etawah Crossbred Goat milk business. But after Community Service, farmers began to think about and calculate the costs incurred in detail, including variable costs and fixed costs during their business. They realized the importance of analyzing the income of the Etawah Crossbred Goatmilk business, because with this analysis they could find out how much income they earned while being able to plan the effectiveness of the use of operational costs to obtain maximum income. 
Furthermore, to increase the knowledge and understanding of business analysis in the field of Etawah Crossbred Goatin Payageli Village, Deli Serdang Regency, further extension is needed so that people are more aware of the importance of conducting business analysis to see the effectiveness of production costs and the feasibility of the business.

2. Changes in the understanding of the Payageli Village of Deli Serdang Regency regarding the analysis of the income of Etawah Crossbred Goatmilk business.

Some respondents claimed that they had understood the analysis of the income of the Etawah Crossbred Goat milk business, so that they could learn to streamline their production costs so that the income earned increased. To improve the understanding of Etawah Crossbred Goatbreeders, further counseling needs to be done again. With good understanding, the farmers can manage their income correctly in accordance with the efficiency of using production costs. In addition, cultivation training and marketing of Etawah Crossbred Goatmilk are needed so that milk production increases and farmers can get good selling prices so that they can increase the income and welfare of farmers.

3. Bookkeeping of the Etawah Crossbred Goatmilk business

Several respondents have tried to book the Etawah Crossbred Goatmilk business. However, the limitations of the time to take part in the training in calculating costs and income and keeping the Etawah Crossbred Goatmilk business in bookkeeping, made them still experiencing difficulties in making bookkeeping.

To increase the knowledge and skills of farmers in making bookkeeping, it is necessary to provide assistance on a regular basis until the farmers are truly proficient and can arrange their own books on the business of their Etawah Crossbred Goatmilk [2, 5].

\section{Conclusion}

The counseling and training that has been carried out shows a positive change in the analysis of the income of the Etawa Breed Goat milk business, because farmers have gained an understanding and knowledge of how to calculate business and income costs, as well as bookkeeping for livestock businesses. Carried out another extension related to the Etawah Crossbred Goatto increase the knowledge of farmers.

\section{References}

[1] Siregar M, Ilham N. 2002. Upaya peningkatan efisiensi usaha ternak ditinjau dari aspek agribisnis yang berdaya saing (Efforts to improve the efficiency of 
livestock business in terms of competitive agribusiness aspects). Pusat Penelitian dan Pengembangan Sosial Ekonomi Pertanian. Bogor.

[2] Ardia A.W. 2000. Analisis pendapatan usaha ternak kambing perah Peranakan Etawa (Analysis of Etawa Peranakan dairy goat business income). Bogor: Jurusan Sosial Ekonomi Industri Peternakan, Fakultas Peternakan, Institut Peranian Bogor.

[3] Chamdi A.N, Qomarudin D.F, Suseno, Kemat A.R, Yuniarso I. 2003. Analisis usaha ternak kambing rakyat di daerah Pedesaan Kecamatan Gumelar Kabupaten Banyumas (Analysis of goat raising the people in the District Rural areas Gumelar Banyumas). Prosiding Seminar Nasional Teknologi Peternakan dan Veteriner. Pusat Penelitian dan Pengembangan Peternakan. Departemen Pertanian.

[4] Saragih B. 2000. Agribisnis Berbasis Peternakan (Animal Husbandry-Based Agribusiness). Kumpulan Pemikiran. USESE Foundation dan Pusat Studi Pembangunan IPB. Bogor.

[5] Yusdja Y, Kariyasa K, Pasandaran E. 2005. Struktur usaha dan pendapatan berbasis skala usaha (Business structure and revenue based on business scale). Badan Penelitian dan Pengembangan Pertanian. Jakarta. 